\title{
"I Have a Kind of Power I Never Knew I Possessed": Surveillance, Agency, and the Possibility of Resistance in YA Dystopian Fiction
}

\author{
SEAN P. CONNORS \\ UNIVERSITY OF ARKANSAS
}

Drawing on Foucault's examination of the gaze as a disciplinary mechanism, and de Certeau's discussion of how people use tactics to resist oppressive power systems, this article advocates reading the gaze in young adult dystopian fiction. To illustrate the complex readings that doing so makes possible, the author examines three young adult dystopias-M. T. Anderson's Feed, Suzanne Collins's Hunger Games trilogy, and Corey Doctorow's Little Brother-to demonstrate how they depict adolescents as having varying degrees of agency to resist the gaze. To conclude, the author discusses the implications for teachers and students of reading the gaze in young adult literature.

An article that was published in the Columbus Dispatch, the daily newspaper in Columbus, Ohio, celebrated the reopening of a local elementary school following an extensive, yearlong renovation of the building. According to the article, several updates were made to the school's digital infrastructure. This included the introduction of wireless Internet and the addition of a new computer lab. As reported by the newspaper, the school's administrators and teachers enthusiastically embraced the updates. Speaking at a school-wide assembly, the principal was said to have

reminded the assembled students that she [had] a favorite new feature: the video surveillance cameras that line the hallways and the building's exterior walls. Being a good student means doing the right thing even when you don't see anybody watching, [the principal] told the group. And "guess what-somebody is almost always watching you." (Bush, 2015, A7)

If one accepts that schools are a microcosm of society, then the suggestion that students exist under the gaze of authority figures is not surprising. In our contemporary "surveillance society" (Lyon, 1994, p. 3), surveillance cameras record people's movements in public and private spaces, 
corporations collect and sell consumers' personal information, and law enforcement is able to monitor people's whereabouts by tracking a signal that is distinct to their cell phone or laptop computer. In short, "To participate in modern society is to be under electronic surveillance" (Lyon, 1995, p. 4). If, however, public schools are, as Dewey (1921) and others argue, crucial to the preservation of a democratic society, then there is something troubling about an educator's aiming to discipline students by admonishing them that "somebody is almost always watching you."

Power is a central concern of young adult fiction (Trites, 2000). This is no less true of young adult (YA) dystopian fiction, a genre that focuses on societies in which rogue governments and (increasingly) corporations use surveillance to manipulate and control teenagers. The gaze is not unidirectional, however, and through challenging students to consider how characters experience surveillance in YA dystopian fiction, educators can create opportunities for them to reflect on how they experience the gaze in their own lives, and how they are capable of resisting, should they so choose, its unprincipled or unethical use.

In the remainder of this article, I draw on Foucault's (1995) examination of the gaze as a disciplinary mechanism and de Certeau's (1984) discussion of how people use tactics to resist oppressive power systems to argue for the value of creating opportunities for students to critically investigate the gaze in YA dystopic fiction. To illustrate the complex readings that doing so makes possible, I examine three contemporary young adult dystopias-M. T. Anderson's (2002) Feed, Suzanne Collins's (2008, 2009, 2010) Hunger Games trilogy, and Corey Doctorow's (2008) Little Brother-to demonstrate how these texts portray adolescents as having varying degrees of agency to resist the gaze. Although my focus in this article is on the dystopic, the framework that I present for examining the gaze lends itself to investigating other genres, including realist fiction. To conclude, I discuss the implications for teachers and students of examining the gaze in literature for adolescents.

\section{POWER AS A CONCERN OF YOUNG ADULT DYSTOPIAN FICTION}

In Disturbing the Universe: Power and Repression in Adolescent Literature, Trites (2000) argues that "power is even more fundamental to adolescent literature than growth" (p. x). Examining the role that institutions such as school, religion, and identity politics play in young adult (YA) fiction, she demonstrates how these institutions alternatively repress and enable adolescent characters. In doing so, she argues that YA literature itself functions as an institution insofar as it socializes 
adolescents to accept their place in extant power systems. Playing on Foucault's (1978) assertion that "power is everywhere" (p. 93), Trites (2000) argues that "in adolescent literature, power is everywhere" (p. x), thus establishing it as a subject worthy of critical investigation.

Connecting the issue of power to YA dystopian fiction specifically, Thomas (2014) argues that the genre provides readers with "a kind of wish fulfilment; not as the life we wish we could live, but as the power and influence we wish we could have” (para. 2). Like Hintz and Ostry (2003), who argue that YA dystopias satiate adolescents' desire for “power and control” (p. 9), Thomas (2014) interprets the genre as a metaphor for adolescence. She notes, for example, that the worlds teenage protagonists inhabit in young adult dystopic fiction are often "full of rules, where all choices are taken away.” Moreover, "[t]hese societies dictate everything about the protagonists' lives, from what they eat and wear to who they marry, how many kids they have, and what careers they pursue" (para 4). Yet if these dystopic societies are undesirable, "they can also be changed" (para. 3). Like Sambell (2004), Thomas (2014) interprets dystopias for adolescents as offering readers "hope that we will overcome the restrictions placed on us" (para. 7). In doing so, the genre acknowledges teenagers' agency, and celebrates their potential to work for social change.

Campbell (2010) identifies power as a central concern of young adult dystopian fiction as well when he argues that the genre challenges readers to "look critically at the power structures that envelop and seek to construct them” (p. 2). He subsequently encourages teachers to create opportunities for students to ask how young adult dystopias position them as subjects. Thomas (2012) adopts a similar stance, arguing that while some contemporary dystopias for adolescents are "excellent, thought-provoking stories, many of them have dangerous messages and old-fashioned, bigoted stereotypes wrapped up in dystopian packaging” (para. 2). Tying the concept of power directly to surveillance, Mallan (2014) argues that YA fiction offers a potentially rich investigative site for examining how adolescents experience the gaze as a form of power, as it has "for some time engaged with contemporary issues and concerns with respect to surveillance, loss of personal liberty, and moral absolutism” (p. 3).

Collectively, these arguments suggest that reading YA dystopian fiction critically, and encouraging students to reflect on the role that disciplinary mechanisms such as the gaze play in their own lives, can position them to see themselves as having the agency to resist (should they so choose) the unprincipled use of these mechanisms, and thus to understand that, as Foucault 
argued, we are always "freer than we think we are" (Bell, 1996, p. 83).

\section{EXAMINING THE GAZE IN YOUNG ADULT DYSTOPIAS}

In Discipline and Punish, Foucault (1995) distinguishes between two modes of power: sovereign power and disciplinary power. As defined by Foucault, sovereign power aims to exert its authority over people with the intention of controlling their behavior (Fendler, 2010). In contrast, disciplinary power aspires to produce “docile bodies" (Foucault, 1995, p. 138) by holding people accountable for exercising power over themselves.

Foucault (1995) interprets the panopticon as a metaphor for understanding how disciplinary power functions in modern societies. A circular structure with a guard tower at its center, the panopticon-an eighteenth century prison-was designed to house prisoners in cells located along the building's perimeter. A small window built into the rear wall of each cell served to backlight the prisoners, ensuring that they remained visible to the guards at all times. The prisoners, on the other hand, were unable to see their captors. Faced with the knowledge that they were potentially surveilled at all times, it was assumed that the prisoners would comply with the behavioral expectations imposed on them. For this reason, Foucault (1995) described visibility as a “trap" (p. 200).

The panoptic metaphor is helpful in explaining how the gaze produces compliance, but it is also characterized by limitations. Flanagan (2014), for example, uses the term "participatory surveillance" to acknowledge that there are occasions when people voluntarily submit themselves to surveillance, as is the case when they participate in "online activities such as shopping and social networking” (p. 128). Taking a different view, Yar (2003) argues that if the gaze were as powerful a disciplinary mechanism as Foucault (1995) assumed, then the only choice people would have to resist it would be to avoid it entirely. Yet there are occasions when people willingly make themselves visible to others for the express purpose of capturing their attention. For example, Yar describes guerrilla theater groups that perform works such as 1984 in front of surveillance cameras with the goal of "revers/ingl the unidirectionality of the gaze, such that the 'guardians of the spectacle' are themselves turned into the objects of moral judgment” (p. 266, italics in original). Likewise, Mann and his colleagues (2003) use the term "sousveillance" to acknowledge practices that people engage in to "resist surveillance through non-compliance and interference 'moves' that block, distort, mask, refuse, and counter-surveil the collection of information” (p. 333). That they 
are able to do so suggests that surveillance is not guaranteed to produce "docile bodies" (Foucault, 1995, p. 135). Instead, people are capable of resisting the gaze and turning it on their surveilors to accomplish their own ends.

Criticizing Foucault for privileging disciplinary mechanisms at the expense of those who experience them, de Certeau (1984) stresses the importance of asking how "society resists being reduced to [disciplinary power], what popular procedures (also 'miniscule' and quotidian) manipulate the mechanisms of discipline and conform to them if only in order to evade them" (p. xiv). People might operate in view of institutions, but, as de Certeau explains, in doing so they adopt "tactics" that allow them to bend situations to their end. As defined by de Certeau, a tactic is a "guileful ruse" that inserts itself in "cracks that particular conjunctions open in the surveillance of the proprietary powers. It poaches in them. It creates surprises in them. It can be where it is least expected" (p. 37). In other words, tactics are moves that allow people to work within existing power systems to accomplish their own ends. As an example, Phipps (2015) explains how street artists hired to graffiti the walls of a background set used in an episode of the popular television show Homeland took advantage of the opportunity to voice their displeasure with what they perceived as the show's racist overtones by including lines such as "Homeland is racist" (para. 2) and "Homeland is a joke, it doesn't make us laugh" (para. 3) in Arabic script. Their tactic went undetected by the show's producers, with the result that the lines were visible to viewers capable of reading Arabic when the episode debuted on television.

Drawing on the above discussion, Figure 1 highlights questions that I suggest teachers and students can ask in the service of reading the gaze in young adult dystopian fiction. The questions are divided into two groups: those that are text-based, and which encourage close reading, and those that invite readers to make text-to-world connections. Note that in addition to asking students to consider how disciplinary mechanisms such as the gaze function in works of YA dystopian fiction, these questions also challenge them to consider how they experience surveillance in their own lives, and how they comply with and resist it and other disciplinary mechanisms. Thus, focusing on The Hunger Games (Collins, 2008), a teacher might invite students to ask: "In the text, who watches others? Who is watched?" At first blush, the answer to this question is seemingly straightforward: through a vast network of cameras and microphones, the Gamemakers, and through them, a television audience, are able to watch Katniss and the other tributes as they compete in the Hunger Games. As Flanagan (2014) argues, however, the situation is in reality 
exceedingly more complex, as there are several occasions when Katniss, adopting the viewpoint of those surveilling her, watches herself to determine how she ought to respond to situations that confront her. Thus, she prevents herself from crying even when she is overcome by feelings of affection for her sister and mother because she understands that to do so would be to lead those watching her to regard her as weak.

Alternatively, to make a text-to-world connection, a teacher might ask students: "When have you experienced surveillance in your everyday life, and how does the knowledge that you are watched influence your behavior?" In doing so, the teacher might encourage students to consider how the manner in which they conduct themselves changes according to the company in which they find themselves-for example, grandparents as opposed to friends as opposed to teachers. Students might also consider whether, like Katniss, they watch themselves in these situations to comply with and/or resist others' expectations of them. In having these conversations with college undergraduates, I am always surprised by the frequency with which they report having taken evasive measures to avoid surveillance in the high schools they attended, a topic that I return to later in this article.

\section{FIGURE 1}

Questions for Reading Disciplinary Power in YA Dystopian Fiction 


\section{Text-Based Questions}

1) What does it mean to be "powerful" in the text? In what ways do characters reveal themselves as "powerful"?

2) When do characters in the text appear to reinforce traditional binaries between "powerful/powerless," "oppressor/oppressed," "strong/weak"? In what ways do they do so?

3) How do characters in the text challenge (or overturn) the aforementioned binaries so that seemingly "powerless" figures are revealed as "powerful"?

4) When are characters in the text surveilled (or watched) by others? How does the knowledge that they are watched influence their behavior?

5) In the text, who watches others? Who is watched? When do characters swap roles, and what tactics allow them to do so?

6) When does the knowledge that they are watched appear to repress characters in the text? When/how do characters use the knowledge that they are watched to their advantage?

7) What tactics allow characters in the text to work within existing power structures to accomplish their goals?

\section{Text-to-World Connections}

1) When, if ever, is it permissible for institutions to surveil people?

2) In what circumstances, and under what conditions, have you experienced surveillance in your life? How did the knowledge that you were watched influence your behavior?

3) What tactics have you used to resist surveillance? 
In the sections that follow, I examine three YA dystopias-Anderson's (2002) Feed, Collins's (2008, 2009, 2010) Hunger Games trilogy, and Doctorow's (2008) Little Brother-with the goal of demonstrating how these novels imagine adolescents as having varying degrees of agency to subvert disciplinary mechanisms such as the gaze. Whereas Feed (Anderson, 2002) imagines the human subject as powerless in the face of corporate surveillance, Collins' (2008, 2009, 2010) Hunger Games trilogy and Doctorow's (2008) Little Brother exemplify Flanagan's (2014) assertion “that individuals can choose to be agentic-not interpellated-surveillance subjects, thus reshaping a concept that has conventionally been associated with disempowerment” (p. 129). My decision to focus on YA dystopias is motivated by the genre's overt concern with political issues, and by its tradition of depicting surveillance as a disciplinary mechanism that authorities use to control people. In this way, YA dystopic fiction offers an accessible beginning point for teachers interested in exploring these issues with students. That said, the above questions also lend themselves to exploring other genres of YA literature, including realist fiction.

\section{THE COST OF RESISTING THE GAZE IN FEED}

Although each of the young adult dystopias that I examine in this article depicts the gaze as a disciplinary mechanism that institutions use to regulate and control people, M. T. Anderson's (2002) Feed is arguably least willing to acknowledge adolescents' potential to resist it. Set in the United States at an undisclosed time in the future, Feed imagines a world in which corporations use technology to surveil and oppress people. Having equipped them with an internet-like device known as a feed, corporations appeal to people's capitalist impulses and greed, inundating them with advertisements for material goods that promise to bring them happiness, but which in actuality hasten their intellectual, moral, and spiritual decay.

In Anderson's (2002) novel, people have a "feed" implanted in their heads at birth, the result of which ensures that they are connected to an internet-like network that continuously serves them television shows, music, trailers for movies, advertisements, and so on. In this society, corporations have managed to gain control of other institutions, thus ensuring that they have access to additional channels through which to disseminate a capitalist ideology that privileges an ethos of individualism at the expense of the collective. Titus, a high school junior and the story's narrator, explains that when his grandparents were young, "schools were run by the government," a concept he finds "completely like, Nazi” (p. 109). When taxpayers were no longer willing to foot the bill for 
public education, corporations stepped in and assumed responsibility for running "School ${ }^{\mathrm{TM}}$." Instead of teaching traditional subjects such as literacy, math, and history, however, School ${ }^{\mathrm{TM}}$ instead instructs students on "how the world can be used" (p. 109), as well as on "how to work technology and how to find bargains" (p. 110). Thus, though he is unable to correctly identify the war in which George Washington fought, Titus accepts the official narrative that corporations are "made up of real human beings, and not just jerks out for money, because taking care of children, they care about America's future” (p. 110).

Throughout the novel, readers are intermittently afforded access to news streams that air on the feed and which suggest that America's corporations have wreaked havoc on the environment, destabilized foreign governments, and inspired riots and protests against the United States government around the globe. Immersed in entertainment and consumerism, however, Titus and his friends are for the most part unaware of these problems. Indeed, a metaphor for their disconnectedness presents itself when Titus and Violet, a girl that he begins dating, speak with a clerk in a mall store about the possibility of their purchasing a high-powered searchlight for Titus's upcar. Pointing to a model he installed on his own vehicle, the clerk recounts an occasion when, while flying home from work, he shined the spotlight on the roofs of the protective domes meant to shield people from the damaging effects of the sun's radiation. The clerk explains:

And all over the top of them, it looked like it was moving, like there was a black goo? So I turned up the brightness, and I went down, and I shined it more bright, and it turned out the black moving goo was all these hordes of cockroaches. There were miles of them, running all over the tops of the domes. (Anderson, 2002, p. 99)

Throughout the novel, the characters' immersion in an ideology of capitalism and consumerism blinds them to the toxicity of corporate culture in much the same way that they are ignorant of the pestilence that swarms the outside of the domes they inhabit.

In Feed (Anderson, 2002), the evolution of technology ensures that corporations are no longer forced to rely on closed-circuit television cameras to surveil people. Instead, people's connectedness to the feed affords corporations uninterrupted access to their dreams, longings, and desires. As is the case in our contemporary surveillance society (Lyons, 1994), corporations in Feed (Anderson, 2002) maintain detailed customer records based on the purchases that people make using the feed. The result, as Violet explains, is that corporations are able to mold people's identities in ways that serve the corporations' own selfish ends. As Violet tells Titus: 
They try to figure out who you are, and to make you conform to one of their types for easy marketing. It's like a spiral: They keep making everything more basic so it will appeal to everyone. And gradually, everyone gets used to everything being basic, so we get less and less varied as people, more simple. (p. 97)

Because she was equipped with a feed later in life, Violet is one of the few characters in the novel who appreciates that she is subject to the gaze of corporations. On an excursion to the mall, she instructs Titus, "Like they're watching us right now. They can tell where you're looking. They want to know what you want” (p. 97). Rather than submit to the gaze, however, Violet instead attempts to resist corporate efforts to reconfigure her identity, a topic that I address in more detail below.

The information that corporations collect about people via the feed is not limited to their material desires. Rather, the feed also permits corporations to access people's emotions, and as a result they are able to inundate them with advertisements for goods that promise to bring them happiness and contentment. When Titus struggles to express himself to Violet in an intimate moment, the feed targets him with an advertisement for pickup lines "tailored extra-specially for this nightmarish scenario" (Anderson, 2002, p. 174). In the midst of an argument between he and Violet, the feed promises, "You low? [. . .] Not for long-not when you found out the savings you can enjoy at Weatherbee \& Crotch's Annual Blowout Summer Fashions Sale!” (p. 274, italics in original). After an anonymous group hacks his feed and exposes Titus to nightmarish images of the destruction that American corporations have wrought around the world, the feed lulls him back to sleep by showing him pictures of beautiful young women, images that Titus describes as "better, not so violent or sucky” (p. 156). In this way, the feed impedes Titus' and his friends' ability to focus on social justice issues, let alone critique-or even be unsettled by-them.

Of course, not everyone is equipped with a feed. Reflecting the class system that structures American society, a percentage of the population is unable to afford one. Other people elect not to outfit their children with a feed, allowing them to choose for themselves whether they wish to have the device when they come of age. This is the case for Violet, who received a feed later in life, and who, due to her father's inability to afford a more expensive one, ended up with a substandard model. Having been raised without a feed, Violet is able to see through the veil that obfuscates other people's understanding of the problems it creates for society, and as a result she appreciates the dangers it poses. Throughout the novel Violet engages in various tactics (de Certeau, 1984) that are intended to resist the feed's gaze and prevent corporations from imposing an identity on her. 
She invites Titus to accompany her to a mall where they spend an afternoon browsing random products they do not intend to purchase. She uses the feed to search for news stories about environmental degradation, political corruption, and global unrest with the goal of becoming a more informed citizen. Nevertheless, Violet's efforts to resist the corporate gaze come at a cost. When a hacker damages her feed, the corporations deny her request to repair it on the grounds that she does not offer them a stable consumer portrait and is therefore not "a reliable investment" (Anderson, 2002, p. 247). She is subsequently left to slip into unconsciousness, caught in a state between life and death, where she is destined to remain until her physical body finally fails her.

Violet's efforts to resist the feed notwithstanding, Feed (Anderson, 2002) depicts adolescents as having relatively little power to resist the gaze. Violet manages to do so in the short term, but she ultimately pays for her transgressions with her life. Likewise, the novel's ambiguous ending leaves readers to question whether Titus has in fact learned anything from his relationship with Violet. He promises to visit her bedside and share news stories about the damage corporations are inflicting on the world, but he also understands that his ability to do so is destined to be compromised by "noise on the feed, the girls in wet shirts offering me shampoo" (p. 296). As a result, he is only able to offer Violet "broken stories. The little pieces of broken stories I could find” (p. 296). Indeed, the last story that Titus tells Violet, and which he refers to as "her story," is infused with a narrative structure that is reminiscent of the advertisements for romance movies that readers encounter throughout the novel courtesy of the feed. Readers are consequently left to wonder if there is any hope for Titus, who, despite his best intentions, appears incapable of resisting either the corporate gaze or the capitalist ideology that the feed inundates him with. Resistance in Feed is, therefore, for the most part presented as futile.

\section{CIRCUMVENTING THE GAZE IN THE HUNGER GAMES TRILOGY}

Suzanne Collins's Hunger Games trilogy $(2008,2009,2010)$ is somewhat more willing to acknowledge adolescents' potential to resist the gaze and other disciplinary mechanisms. Reflecting Mann et al.'s (2003) use of the term sousveillance to refer to tactics that people use to "block, distort, mask, refuse, and counter-surveil the collection of information” (p. 333), the Hunger Games acknowledges that, under some circumstances, people are able to turn the gaze back on itself and work within oppressive power systems to accomplish their own ends. 
Foucault's (1995) discussion of panopticism offers a helpful framework for considering how disciplinary power functions in the world that Katniss Everdeen, the protagonist in the Hunger Games trilogy, inhabits. To begin, the districts that comprise Panem are isolated from one another geographically, making travel between them on foot difficult. The Capitol takes additional steps to limit people's mobility. A chain-link fence encloses the perimeter of District 12, which Katniss and her family call home. While the official government narrative is that the fence exists to protect the districts from predators that roam the forests, it also holds their residents in a fixed location. By securing the districts in this way, the Capitol severs the lines of communication between them, thus minimizing the likelihood of their organizing to promote their own interests. As Katniss states, "It's to the Capitol's advantage to have us divided among ourselves" (Collins, 2008, p. 14).

The Capitol also arranges Panem in a hierarchy, with the result that individual districts are divided against each other. At the apex is the Capitol, whose citizens enjoy a range of comforts and luxuries, and whose access to technology ensures its military dominion over its enemies. Beyond that are the districts, some of which are more affluent than others as a result of their having courted the Capitol's favor. According to Katniss, the Capitol coddles the inhabitants of District 2, who "swallowed the Capitol's propaganda more easily," and who subsequently came to regard the Hunger Games not as a form of subjugation, but as "an opportunity for wealth and a kind of glory not seen elsewhere” (Collins, 2010, p. 193). Residents of District 2 also aspire to become Peacekeepers, a position that requires them to brutalize and oppress residents of other districts. On the other hand, District 12, where Katniss and her family live, is described as one of the poorest districts in Panem.

In its relationship with the districts, the Capitol occupies a position that approximates the guard tower in Foucault's (1995) panopticon. Although it does not reside at the geographical center of Panem, the Capitol nonetheless engages in a range of surveillance practices that are intended to fix the districts in its gaze and enforce compliance. To support the Capitol's ability to spy on its enemies, scientists working for the state genetically engineered a special strain of bird known as the jabberjay, a creature that is capable of replicating the human voice and repeating passages of conversation (Collins, 2009, pp. 91-92). Katniss also acknowledges the existence of paid informants who spy on their neighbors on behalf of the Capitol (p. 152). Most important, the Capitol places surveillance cameras throughout the districts, offering it a window onto the lives of 
those it governs. Cognizant that they are watched, the people of Panem seemingly have no alternative but to comply with the Capitol's expectations. Yet, as their actions demonstrate, they are not without power.

The story of the jabberjay offers a compelling metaphor for understanding how characters in the Hunger Games trilogy (Collins, 2008, 2009, 2010) use tactics (de Certeau, 1984) to leverage their power and resist the gaze and other disciplinary mechanisms. As Katniss explains, the jabberjay is a genetically engineered bird that scientists working for the Capitol created for surveillance purposes (Collins, 2009, pp. 91-92). Given its ability to repeat extended passages of dialogue, the jabberjay represents a "strategy" (de Certeau, 1984) that the Capitol employs to spy on its adversaries. Eventually, rebel fighters figured this out, and they responded with a simple, but effective tactic that allowed them to turn the situation to their advantage: they fed the birds lies, which the jabberjays in turn carried back to the Capitol. Thwarted, the Capitol abandoned the jabberjay project, assuming that the birds would go extinct. Before that could happen, however, the all-male jabberjays mated with female mockingbirds, creating a new breed of bird known as the mockingjay (Collins, 2009, pp. 91-92). The mockingjay thrived in the wild, and for the people of Panem, it came to symbolize the Capitol's failure. As Katniss explains, leaders in the Capitol "hadn't counted on the highly controlled jabberjay having the brains to adapt to the wild, to pass on its genetic code, to thrive in a new form. They hadn't anticipated its will to live” (2009, p. 92).

The parallels between the story of the mockingjay and Katniss's own experiences in the Capitol are striking. As it had the jabberjay, the Capitol repeatedly overestimates its ability to manipulate and discipline Katniss. In her quest to survive the Hunger Games and return home to District 12, however, she proves a clever adversary. Throughout the series she engages in a variety of tactics that allow her to work within the system the Capitol has created to subvert the disciplinary mechanisms it attempts to impose on her. Faced with the knowledge that she is surveilled by television cameras, Katniss conforms to the behaviors she assumes her audience expects of her. She consequently receives gifts from wealthy sponsors, which offers her a distinct tactical advantage in the arena. She and Peeta also feign a romantic relationship that establishes them as audience favorites, making it more difficult for the Capitol to dispose of them. Knowing that television cameras carry their image into homes throughout Panem, they threaten to consume poisonous berries, the result of which forces the Gamemakers to declare them co-victors. These acts of resistance are seldom spectacular. Instead, Katniss works quietly within the power system the 
Capitol erects to turn it to her advantage. It is surely no coincidence that she, like the jabberjay, undergoes a metamorphosis over the course of the series, ultimately transforming into the Mockingjay, a symbol of resistance and revolution.

\section{SOUSVEILLANCE IN LITTLE BROTHER}

Like Collins's (2008, 2009, 2010) Hunger Games trilogy, Doctorow's (2008) young adult novel Little Brother invites readers to imagine a dystopian society in which an oppressive government uses technology to surveil and control its citizens. Yet whereas the Hunger Games is set in the distant future, Little Brother takes place in a world that readers will recognize as similar to their own. Throughout the novel, Doctorow calls attention to the role that institutions such as school and government play in using the gaze as a mechanism to promote discipline. As Marcus Yallow, the novel's protagonist and narrator, explains in the story's opening line: "I'm a senior at Cesar Chavez High in San Francisco's sunny Mission district, and that makes me one of the most surveilled people in the world" (p. 9).

Surveillance takes many forms at the high school Marcus attends. Software loaded onto district-provided laptops ensures that school officials are able to track students' internet searches and monitor their email. Radio frequency ID tags embedded in the binding of books permits school librarians to maintain circulation records, but also allows school leaders to track students' movements on campus. After a court ruled that the use of facial recognition software in schools was unconstitutional, the school district in which Marcus is enrolled diverted funds that might otherwise have been used to purchase textbooks and instructional resources to install gaitrecognition cameras. As a result, school officials are able to identify truant students based on the length of their stride. Yet as Marcus explains, each new layer of surveillance the school introduces paradoxically renders it more susceptible to attack, as it creates the illusion of inviolability, thus lulling the "faculty into a totally false sense of security" (Doctorow, 2008, p. 21).

Throughout Little Brother, Doctorow (2008) depicts school as an institution that exists to discipline students and to preserve the status quo. Following a terrorist attack on San Francisco, Marcus's school district places security cameras in classrooms, ostensibly to ensure student safety; in actuality, however, these devices allow school leaders to monitor the actions and discourse of teachers and students. Questioning the district's motives, Marcus initiates a debate in his social studies class about the wisdom of surrendering one's privacy for safety. When the debate escalates, 
his teacher, Ms. Galvez, terminates it out of concern that the topic is "too emotional" for a class discussion. Ironically, she redirects the students' attention to their study of the suffragists, a group that resisted institutional authority using tactics designed to secure women the right to vote. Later, when the same teacher instructs students in Marcus's class about how young people in the 1960s and 1970s used tactics to fight for civil rights, disrupt oppressive political ideologies, and challenge oppressive institutions, she is unceremoniously fired and replaced with a teacher who conforms to the district's expectations and who insists that the government is within its rights to suspend freedoms during times of civil unrest.

If Anderson (2002) regards adolescents as having relatively little power to resist the gaze, and Collins (2008, 2009, 2010) imagines them as working within oppressive systems to accomplish their own ends, Doctorow (2008) celebrates teenagers' ability to engage in sousveillance (Mann et al., 2003) and actively resist those who would use disciplinary mechanisms (most notably surveillance) to oppress and control them. In a nod to Orwell's (1949/1987) 1984, the technologysavvy Marcus adopts the screen name "W1n5ton" (pronounced Winston), which permits him to anonymously engage in tactics that are designed to subvert his high school's unprincipled use of disciplinary mechanisms. Recognizing that his school-provided laptop allows officials to monitor his use of the internet, Marcus exploits a "crack" in the system that permits him to install software that is invisible to the school district, but which affords him "a little control over the box" (Doctorow, 2008, p. 14). Prior to leaving campus without permission, he places a friend's textbook in a microwave for thirty seconds, disabling its radio frequency ID tag. To elude the gaze of the school's gait-recognition cameras, Marcus employs an even more rudimentary tactic: he places a handful of stones in his shoes, which alters his gait and allows him to escape the surveillance system undetected. When, early in the novel, a school administrator comes close to identifying Marcus as "W1n5ton," he abandons the screen name, adopting the moniker "M1k3y" (Mikey) instead. In this way, Doctorow establishes his novel as distinct from Orwell's (1949/1987). Winston might succumb to the gaze of Big Brother, but in Little Brother (Doctorow, 2008), Marcus's use of tactics permits him to resist oppressive institutions by successfully exploiting fissures in the very power structures they create.

If Little Brother (Doctorow, 2008) is skeptical of the role that school plays in disciplining teenagers to accept their place in the power structure, it is even more suspicious of a government that abuses its power in the name of preserving public safety. The novel is an obvious critique of 
the Patriot Act, which the United States Congress enacted in the wake of the 9/11 terrorist attacks, and which authorized the government to collect data on citizens using a variety of surveillance measures. After terrorists blow up the Bay Bridge and flood an underground train tunnel in the San Francisco Bay area, killing thousands of commuters, Marcus and his friends are mistakenly detained in a series of mass arrests carried out by agents working for the Department of Homeland Security (DHS). Held for days on end without the opportunity to seek council and subjected to harsh interrogation methods, Marcus eventually surrenders the passwords for his cell phone, USB keys, and email account. Prior to his leaving the makeshift prison where he is held, a DHS agent cautions Marcus not to interpret his release as a sign that he is above suspicion. "[F]rom now on, you belong to us” (p. 64), she explains, a chilling reminder of both the government's power and the scope of its reach.

Ashamed that he surrendered his private information so easily, and concerned about a friend who remained in the DHS prison, Marcus returns to a San Francisco he barely recognizes. Unmarked white tractor-trailers like the one he and his friends were held in occupy the city's streets. Sensors and surveillance cameras are positioned at traffic intersections, and the DHS uses people's electronic tollbooth passes to monitor their travel and to identify deviations in their driving routes. More disturbing, Marcus discovers that the DHS bugged his personal computer. Cognizant that " $[t]$ here were eyes out there, eyes and ears, and they were watching me. Surveilling me," Marcus realizes that "the surveillance [he] faced at school had followed [him] home" (Doctorow, 2008, p. 84).

As he had at school, Marcus again uses technology to resist the government's gaze, suggesting that technology is not simply a tool of the oppressor, but a tactic for resisting oppression. Rather than cease using his laptop altogether, Marcus instead modifies his web-surfing practices to give those surveilling him the impression that he is changing his habits. He teaches other likeminded people who follow "M1k3y" to build a device they can use to transfer ownership of tollbooth passes, the result of which impedes the DHS's ability to surveil people's driving patterns and creates chaos, forcing the DHS to abandon the program. Much as rebel fighters seize on the jabberjay as an opportunity to disseminate misinformation in the Hunger Games trilogy (Collins, 2008, 2009, 2010), Marcus and his contemporaries feed the DHS operatives that surveil them false information. Describing the value of this tactic, Marcus states: 
If you want, you can make [a spy] seem erratic and unreliable so they get rid of him. You can manufacture crises that might make one side or the other reveal the identities of other spies. In short, you own them. (Doctorow, 2008, p. 150)

Rather than let the government use technology to repress them, Marcus and his followers instead devise tactics that permit them to leverage technology in ways that empower them. This is not lost on Marcus, who reflects:

The best part of all of this is how it made me feel: in control. My technology was working for me, serving me, protecting me. It wasn't spying on me. This is why I loved technology: if you use it right, it could give you power and privacy (p. 88, emphasis in original)

In the dystopian society that Doctorow (2008) imagines, teenagers are not powerless in the face of the gaze. Quite the opposite, they are depicted as using technology in ways that empower them. In doing so, they demonstrate to readers that, in the words of Foucault, people are always freer than they think they are (Bell, 1996, p. 83).

\section{CONCLUSION}

The question thus arises: why should teachers and students be concerned with reading the gaze in young adult dystopian fiction, or other genres of young adult literature for that matter? To begin, teachers and students experience surveillance and other disciplinary mechanisms on a daily basis. According to Monahan and Torres (2010), "well-known mechanisms of student and teacher discipline include high-stakes standardized testing, zero-tolerance policies for violence, rigid schedules, and architectures of visibility and containment” (p. 1). Moreover, Taylor (2013) identifies teenagers as "the most heavily surveilled population in countries such as the United Kingdom and United States" (p. 3). Today, a growing number of schools are turning to surveillance technologies to enforce compliance. The practice of using closed circuit television cameras and identification cards embedded with microchips that enable school officials to track students' movements is already prevalent in many school districts, and, according to Taylor, "biometric measures such as fingerprinting, iris scanning and palm vein readers are finding their ways onto campuses” (p. 2). In using surveillance to enforce compliance, Harris (2011) argues that schools are guilty of choosing "authoritarianism for children, sold to students and staff using the dazzle of technology, and the modern vocabulary of the security crackdown" (para. 8). If this is the case, it is important that students are given opportunities to consider how they experience 
surveillance in their daily lives, and to determine when, if ever, people are justified in resisting it and other disciplinary mechanisms.

In 2012, at the Assembly on Literature for Adolescents (ALAN) Workshop in Las Vegas, I had the opportunity to hear a panel of young adult authors discuss their work writing speculative fiction for adolescents. One of them, Scott Westerfeld, half-jokingly suggested that dystopic fiction is perfectly suited for young adults because high school is itself a dystopia. Perhaps there is more truth to Westerfeld's observation than one might care to admit. In a high school, a large number of students are divided into smaller, more manageable groups and partitioned into separate classrooms. Throughout the day their movements are dictated by a rigid timetable, with a bell signaling when it is time to change locations. In the current education reform era, students are subjected to a barrage of standardized assessments, which are in turn used to sort and rank them. In an age when school violence is disturbingly commonplace, surveillance technologies have infiltrated schools, ostensibly in the name of maintaining safety. In some neighborhoods, students enter school and pass through metal detectors under the watchful gaze of security guards. Other schools make use of closed-circuit television cameras that are strategically placed throughout campus to monitor and record students' movements. As the principal in the anecdote that began this article suggested, it seems that in school someone is almost always watching students.

Teenagers are not passive victims of surveillance, however. Indeed, it is possible to appreciate the creative tactics they use to resist the gaze and other disciplinary mechanisms that schools attempt to impose on them. In Providence, Rhode Island, for example, a group of students dressed as zombies and marched in front of the state capitol to protest a requirement that tied their ability to graduate from high school to their earning a cut score on a state assessment (Zezima, 2013). By making themselves visible to the gaze of television cameras, these students directed attention to the politicians whose policies they opposed. Drawing on findings from a research study she conducted in a public school in New York City, Weiss (2010) described a series of tactics students used to circumvent the surveillance mechanisms that school leaders imposed on them. These tactics included their befriending security guards entrusted with surveilling them, finding alternative routes through the building to avoid the gaze of guards, and staging a walkout that functioned to disrupt the school day and call attention to school leaders. Faced with disciplinary mechanisms, the students in Weiss's study found creative ways to subvert them. 
Although it is not directly related to school, Gamber-Thompson and Zimmeran (2016) offer a still more powerful example of how contemporary young people are resisting the gaze by making themselves visible to it. They describe a 2011 grassroots activist campaignNational Coming Out of the Shadows Week-in which teenagers and young adults uploaded video testimonials to YouTube and other social media platforms in which they "came out" as undocumented immigrants living in the United States. By choosing to make themselves visible, these young people put themselves at considerable risk. At the same time, as Gamber-Thompson and Zimmeran argue, they paradoxically stood to gain strength in numbers as their individual stories merged with other stories shared by people facing similar circumstances. Furthermore, in choosing to share their often emotionally charged stories publicly, these young people put a human face on an otherwise abstract issue, thus calling attention to punitive laws that marginalize undocumented immigrants living in the U.S. As the author of one of these testimonials explained, in the current sociopolitical climate, "Remaining in the shadows is no longer acceptable" (p. 217).

The prospect of encouraging students to consider how they experience the gaze in their lives, and when, if ever, they are justified in resisting it, may make some educators uncomfortable, especially in our current education reform era when schools often appear to emphasize standardization and authoritarianism at the expense of diversity and freedom of thought. Others might work with young people who perceive surveillance as a necessary safeguard in our post-9/11 world, and who might take issue with the suggestion that they ought to avoid or resist it. This is a legitimate concern, and it warrants attention.

First, when we refer to surveillance, it is important to acknowledge, as various scholars have, the different forms that this practice takes. Flanagan (2014), for example, distinguishes between oppressive surveillance and what she calls "participatory surveillance," which she understands to involve people's voluntarily choosing to take part in practices that expose them to data collection-for example, shopping online or browsing corporate web sites (p. 128). One might also note that in contemporary society, surveillance is often conflated with entertainment, as is the case in the genre of reality television. Paradoxically, these seemingly innocuous forms of surveillance are in fact problematic, as they have the potential to "seduce participants into a stunning conformity of which some seem scarcely conscious (Lyon, 2006, p. 8). That said, in making the argument that I have in this article, I do not mean to imply that educators have a responsibility to persuade students to resist surveillance altogether. Rather, the point is that 
teachers should support students understanding the myriad forms that surveillance can take so that they can decide for themselves whether or not they wish to participate in these practices.

Second, some readers may take umbrage with the idea of teachers asking students to explore questions and issues like the ones that I have examined in this article on the grounds that to do so is to bring politics into the classroom. It should be noted, however, that a decision not to address these issues in school is also a political act given that it naturalizes not only surveillance, but also compliance. P. L. Thomas (2013) makes this point strongly, characterizing the choice to remain silent and appear "objective" as "political acts that maintain the status quo of privilege." Confronted with oppressive systems, Thomas argues, teachers (and by extension, students) face a choice: “Act or be the tools of other people's actions" (p. 165, emphasis in original).

By creating opportunities for students to reflect on the ends toward which characters in YA dystopias put tactics in the service of resisting oppressive power systems, teachers do precisely this: they invite students to acknowledge their own potential to act. At a time when authoritarian and extremist tendencies resonate with an alarmingly large segment of the population, I respectfully argue that as educators, we ought to aspire to produce Mockingjays, not Career Tributes who are willing to exist comfortably in a society that privileges some people and marginalizes others. By creating opportunities for students to read the gaze in YA dystopian fiction and other genres of YA literature, educators can challenge them to approach these books in much the same way they would other texts-that is, by interrogating the social knowledge they reproduce. Furthermore, by inviting students to reflect on occasions when they, like Katniss or Marcus, engaged in tactics designed to resist authoritarian practices, educators can create opportunities for them to understand themselves as people capable of resisting the unprincipled use of surveillance and of working for change within society. 


\section{REFERENCES}

Anderson, M. T. (2002). Feed. Cambridge, MA: Candlewick Press.

Bell, V. (1996). The promise of liberalism and the performance of freedom. In A. Barry, T.

Osborne, \& N. Rose (Eds.), Foucault and political reason: Liberalism, neo-liberalism, and rationalities of government (81-97). Chicago, IL: University of Chicago Press.

Bush, B. (2015, January 6). Stewart school reopens to raves. The Columbus Dispatch, pp. A1, A7. Campbell, J. W. (2010). The order and the other: Power and subjectivity in young adult literature. (Unpublished doctoral dissertation). Illinois State University, Normal, IL.

Collins, S. (2008). The hunger games. New York, NY: Scholastic.

Collins, S. (2009). Catching fire. New York, NY: Scholastic.

Collins, S. (2010). Mockingjay. New York, NY: Scholastic.

de Certeau, M. (1984). The practice of everyday life. Berkeley, CA: University of California Press.

Dewey, J. (1921). Democracy and education: An introduction to the philosophy of education. New York, NY: MacMillan. (Original work published 1916)

Doctorow, C. (2008). Little brother. New York, NY: Tor.

Fendler, L. (2010). Michel Foucault. London: Continuum.

Flanagan, V. (2014). Technology and identity in young adult fiction: The posthuman subject. New York, NY: Palgrave Macmillan.

Foucault, M. (1978). The history of sexuality, vol. 1: An introduction. (Robert Hurley, Trans.). New York: Pantheon.

Foucault, M. (1995). Discipline and punish: The birth of the prison. (A. Sheridan, Trans.). New York, NY: Vintage Books. (Original work published 1977)

Gamber-Thompson, L., \& Zimmerman, A. M. (2016). DREAMing citizenship: Undocumented youth, coming out, and pathways to participation. In H. Jenkins, S. Shresthova, L.

Gamber-Thompson, N. Kligler-Vilenchik, \& A. M. Zimmerman, By any media necessary: The new youth activism (pp. 186-218). New York, NY: New York University Press.

Harris, J. (2011). School surveillance: how big brother spies on pupils. The Guardian. Retrieved from http://www.theguardian.com/uk/2011/jun/09/schools-surveillance-spying-on-pupils

Hintz, C., \& Ostry, E. (2003). Introduction. In C. Hintz \& E. Ostry (Eds.), Utopian and dystopian writing for children and young adults (pp. 1-20). New York, NY: Routledge. 
Lyon, D. (1994). The electronic eye: The rise of surveillance society. Minneapolis, MN: University of Minnesota Press.

Lyon, D. (2006). The search for surveillance theories. In D. Lyon (Ed.), Theorizing surveillance: The panopticon and beyond (pp. 3-20). Portland, OR: Willan Publishing.

Orwell, G. (1949/1987). 1984. New York, NY: Signet Classic.

Mallan, K. (2014). Everything you do: Young adult fiction and surveillance in an age of security. International Research in Children's Literature, 7(1), pp. 1-17.

Mann, S., Nolan, J., \& Wellman, B. (2003). Sousveillance: Inventing and using wearable computing devices or data collection in surveillance environments. Surveillance \& Society, 1(3), 331-355.

Monahan, T., \& Torres, R. D. (2010). Introduction. In T. Monahan and R. D. Torres (Eds.), Schools under surveillance (pp. 1-18). New Brunswick, NJ: Rutgers University Press.

Phipps, C. (2015). 'Homeland is racist': artists sneak subversive graffiti on to TV show. The Guardian. Retrieved from https://www.theguardian.com/tv-andradio/2015/oct/15/homeland-is-racist-artists-subversive-graffiti-tv-show

Sambell, K. (2004). Carnivalizing the future: A new approach to theorizing childhood and adulthood in science fiction for young readers. The Lion and the Unicorn, 28(2), 247-267.

Taylor, E. (2013). Surveillance schools: Security, discipline, and control in contemporary education. Houndmills, Basingstoke, Hampshire; New York, NY: Palgrave MacMillan.

Thomas, P. L. (2013). Radical scholar as public intellectual in a marketplace of ideas.

In E. A. Daniels \& B. Porfilio (Eds.), Dangerous counterstories in the corporate academy: Narrating for understanding, solidarity, resistance, and community in the age of neoliberalism (pp. 145-168). Charlotte, NC: Information Age Publishing.

Thomas, R. (2012). The dystopian in ya dystopias. Feminist Fiction [Blog post]. Retrieved from http://feministfiction.com/2012/09/05/the-dystopian-in-ya-dystopia/

Thomas, R. (2014). Wish fulfilment in ya dystopia. Feminist fiction [Blog post]. Retrieved from http://feministfiction.com/2014/04/11/wish-fulfilment-in-ya-dystopia/

Trites, R. S. (2000). Disturbing the universe: Power and repression in adolescent literature. Iowa City, IA: University of Iowa Press. 
Weiss, J. (2010. Scan this: Examining student resistance to school surveillance. In T. Monahan \& R. Torres (Eds.), Schools under surveillance: Cultures of control in public education (pp. 313-229). New Brunswick, NY: Rutgers University Press.

Yar, M. (2003). Panoptic power and the pathologisation of vision: Critical reflections on the Foucauldian thesis. Surveillance \& Society, 1(3), 254-271.

Zezima, K. (2013). More parents opting kids out of standardized tests. Retrieved from http://www.northjersey.com/news/more-parents-opting-kids-out-of-standardized-tests1.589429

SEAN P. CONNORS is an associate professor of English education in the College of Education and Health Professions at the University of Arkansas. His research focuses on the application of diverse critical perspectives to young adult literature. 